\title{
Tools for Increasing the Efficiency of Using Fixed Assets in the Context of Digital Transformation of the Economy
}

\author{
Tatyana V. Kudryashova $1 *$ [ORCID 0000-0003-4056-3855], \\ Elena F. Zhukova 1[ORCID 0000-0002-9443-7363], \\ Natalya V. Subbotina 1[ORCID 0000-0002-8096-6053]
}

\author{
${ }^{1}$ Yaroslav-the-Wise Novgorod State University, Veliky Novgorod, Russia \\ Tatyana.Kudryashova@novsu.ru
}

\begin{abstract}
The most important factor in increasing the production efficiency of an enterprise is its provision with fixed assets in sufficient quantity and assortment, as well as its fullest possible use to achieve the development goals of an economic entity. The well-organized management of their use is the basis for improving the efficiency of the fixed assets of an enterprise. In modern realities, the successful activity of any organization depends on the ability to adapt to rapidly changing environmental factors, as evidenced, among other things, by the epidemiological situation in the world. Russia, like all countries, is in a state of digital transformation, increasingly introducing digital tools in the management of various processes. The use of digital technologies in various sectors of the economy is becoming an integral feature of modern reality. The article presents an analysis of the process of digitalization of business in Russia, including in the context of certain types of economic activity. The indicators of the development of the digitalization process are highlighted, which are ERP-, CRM-, SCM-systems. The existence of positive practices for the use of digital tools in the activities of various enterprises is noted. The leading types of economic activity in the Russian economy in terms of digitalization are identified. An algorithm for managing the fixed assets of an organization is presented. The key areas in the management of fixed assets of an organization are noted, where digital tools are the basis for its effective use these are various elements of EAM (Enterprise Asset Management). The article also noted a large gap between the leading enterprises in the use of digital tools for managing fixed assets and the bulk of enterprises. As a recommendation, domestic enterprises are invited to use the basic EAM models as the first step towards digital asset management.
\end{abstract}

Keywords: fixed assets, fixed assets management, digital tools, efficiency of fixed assets use

\section{INTRODUCTION}

As you know, any functioning enterprise can always be characterized by a system of indicators that reflect how efficiently fixed assets are used in the production process or other form of activity.

Fixed assets management still remains an urgent task for many enterprises not only in Russia, but throughout the world, and this applies not only to manufacturing, but also to construction, transport, trade, telecommunications and many other organizations.
Modern research in the field of fixed assets management pays serious attention to both the conceptual apparatus of these categories [1, 2], analysis, evaluation, accounting of fixed assets [2-5], and investment in fixed assets and the efficiency of its use at the micro- and meso-levels [6-12].

Recognizing the importance of these studies, it can nevertheless be noted that the papers do not pay enough attention to the use of digital tools to improve the efficiency of the use of fixed assets, while real business speaks with might and main about the need for their use in modern conditions. 
So, for example, L. Vinokurov, vice president for business development at Interprocom, notes in his interviews that "the immediate prospects for the development of fixed assets management systems are associated with the use of new digital technologies: their availability and scale of use will steadily grow" [13, 14]. The development of the digital economy has led to the emergence of research in the field of digitalization of enterprises. For example, attention is paid to the impact of digitalization on the problems of employment of workers [15], the prospects for the formation of digital networks and optimization of value chains [16], the possibilities of digital transformation in the electric power industry [17], including taking into account the greening of processes [18] and others

In this regard, it seems relevant to study the prospects and opportunities for digitalization of management processes and the use of fixed assets of enterprises in the context of general trends in the development of the digital economy.

\section{MATERIALS AND METHODS}

The purpose of this research is to study the process of digitalization of fixed assets management and search for promising tools to increase the efficiency of its use in the context of the digital transformation of the economy. The stated goal predetermined the objectives of the study, the main ones being:

- analysis of the level of development and use of digital technologies in the Russian economy;

- studying the experience of using digital technologies in the management of fixed assets with the highlighting of the most successful practices;

- offer the most effective digital tools for the use and management of fixed assets.

The research methods used in the work are scientific methods of empirical and theoretical knowledge, such as observation, description, comparison, formalization, deduction; as well as general logical methods and techniques of cognition, such as analysis, synthesis, generalization, induction, a systematic approach, etc.

\section{RESULTS}

Fixed asset management is a complex process that is carried out in accordance with a certain algorithm containing certain key stages.

1) Establishment and selection of the objectives of fixed asset management.

2) Postulation of the basic principles of fixed assets management.

3) Definition of key methods of fixed asset management.

4) Implementation of a fixed asset management system at the enterprise and development of actions that contribute to obtaining an effective result, indicated in the early stages.

First of all, it is necessary to determine the goals of fixed asset management, while highlighting the most basic ones. L.V. Davydova and S.A. Ilminskaya [6] distinguish the following goals of fixed asset management:

- increasing the technical level of fixed assets;

- reducing the cost of servicing obsolete fixed assets and their improvement through effective investment to achieve the required level of profitability;

- identification of possible reserves for the efficient use of fixed assets;

- evaluation of the effectiveness of possible options for changing and developing fixed assets.

Each of the listed goals of fixed asset management can be decomposed to the level of individual tasks and subtasks that must be solved in order to achieve the goals. Among the most significant tasks are the following:

1) Raising the required amount of assets. If we are talking about raising the technical level of fixed assets, then, first of all, it should be understood how this increase will occur. Perhaps investments will be attracted. Another way is to use equipment rental or leasing for the required fixed assets (leasing can be used on favorable terms for the enterprise).

2) Achieving an acceptable rate of return on fixed assets. One of the goals of managing the fixed assets of an enterprise is to reduce the cost of maintaining obsolete fixed assets and their improvement through effective investment in order to achieve the required level of profitability. There are no exact standards for the return on fixed assets, since much depends on the field of activity, the size 
of the enterprise and the specifics of production. However, if the profitability ratio varies from $100 \%$ to $200 \%$, then this may indicate low competition in the industry where the company operates, or, conversely, high prices. There may also be a situation when an enterprise saves on all resources, using cheap and low-quality raw materials. In each case, a comprehensive analysis of factors affecting profitability should be carried out.

3) Ensuring reserves for the efficient use of fixed capital. In order to provide the enterprise with reserves of fixed assets, it is necessary to understand how this replenishment will occur. This may include:

- commissioning of unused and uninstalled equipment;

- replacement and modernization of fixed assets;

- increasing the efficiency ratios for the use of fixed assets;

- development of new technologies;

- increase in the share of the active part of fixed assets, etc.

4) Identification of possible options for the development of fixed assets. In order to have development options that will lead to an increase in the efficiency of the use of fixed assets, it must be remembered that each managerial decision made must be deliberate and consistent with the chosen development strategy of the enterprise, comply with its technical equipment plan and at the same time contain minimal risks.

In addition to the goals of fixed asset management and their corresponding tasks, it is important to note the basic principles of fixed asset management. These include:

- use of fixed assets for its intended purpose;

- ensuring safety, rational use and acceleration of turnover;

- rationing, which will make it possible to economically correctly establish the required amount of fixed assets, thereby ensuring conditions for the effective use and performance of its functions.

Compliance with these principles is one of the important conditions for the effective management of fixed assets.

The choice of effective methods for managing the company's fixed assets is a key criterion for building a high-quality and sustainable model for the development of an enterprise.

These goals and methods of managing fixed assets are familiar to a certain extent to every head of the enterprise. But the tools to achieve these goals may be different. And at the moment, it is important for archi to use digital tools, because they serve as a competent basis for the management and use of fixed assets, which will improve the overall efficiency of the business and make the enterprise more sustainable and competitive.

Reducing production costs, increasing productivity, minimizing unscheduled stops and downtime, preventing accidents and disasters - all these are arguments in favor of starting to use fixed assets efficiently using modern digital and information technologies.

After a full-fledged work has been carried out on the formation of a system for managing the fixed assets of an enterprise, which consists in determining the goals, objectives, principles and methods of management, one should proceed to its implementation.

There are several typical stages in the implementation of such an implementation.

1) Preparation of intra-organizational mechanisms for information interconnection.

2) Preparation of the internal organizational base. Fixed asset management implies the use of various technologies with the help of which the distribution of fixed capital is carried out.

3) Ensuring compliance with the accepted principles and methods of asset management.

And at each of these stages, digital tools are now assigned a significant, and sometimes decisive role.

The presented procedure for managing the company's fixed assets in the course of its development may change both in terms of methods, structure, and in relation to the tools used. In this case, any change must always be accompanied by appropriate adjustments to the very components of the asset management system.

It should be noted that the undoubted factor that accelerated the processes of digitalization was the epidemiological situation around the world caused by COVID-19. 
The current trend in the development of the world economy is steadily connected with the processes of digitalization. First of all, it concerns business development. According to the business digitalization index, Russia lags behind many European countries (Figure 1), which creates serious challenges for Russian business on the way to a high level of competitiveness in the context of globalization.

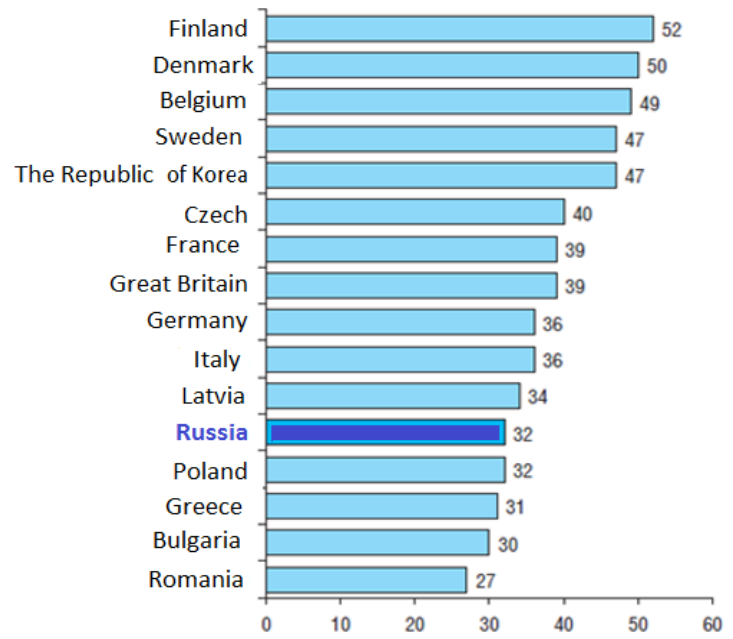

Figure 1. Business Digitization Index by Country, 2019

Source: [19]

The share of gross domestic costs for the development of the digital economy in Russia in 2019 amounted to 4.094 billion rubles. $3.7 \%$ of GDP), which is slightly higher than the previous year (3.6\% of GDP in 2018).

Of interest is the analysis of the index of digitalization of Russian business in the context of types of economic activity (Figure 2).

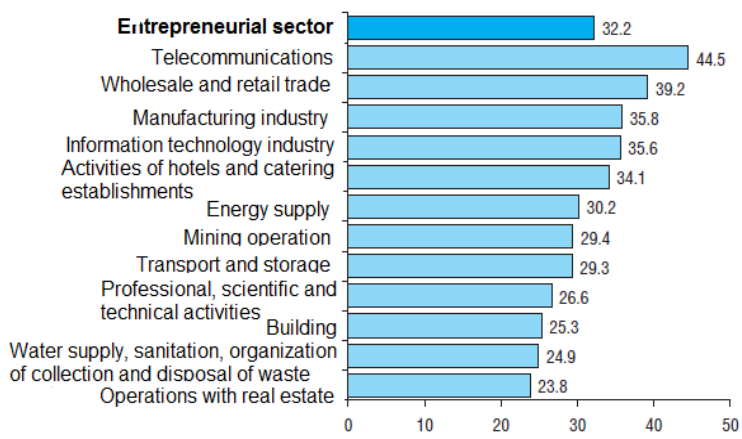

Figure 2. Index of digitalization of Russian business by type of economic activity, 2019

Source: [19]

If we talk about the structure of internal costs of organizations for the creation, distribution and use of digital technologies by type of economic activity, it is expected that the leading position here is occupied by "Information and Communication" (21.6\%). Next come such types of economic activity as "Professional, scientific and technical activities" (19.7\%), "Financial and insurance activities" (15.5\%), "Education" (12\%), "Manufacturing industry" (7.2\%), "Wholesale and retail trade" $(6.1 \%)$ and further in descending order [19]. It is noteworthy that such capital-intensive types of economic activity as "Construction", "Agriculture" allocate less than $2 \%$ to digital technologies in the structure of internal costs. There is a huge potential for growth in the digitalization of these activities.

If we analyze the structure of internal costs of organizations for the creation, distribution and use of digital technologies and related products and services by type, then the lion's share (about 90\%) falls on three areas [19]:

- purchase of machinery and equipment related to digital technologies (44.4\%);

- purchase of software, its adaptation and improvement $(24.5 \%)$;

- payment for telecommunication services $(18.7 \%)$.

This structure of investment in assets is quite logical and meets the signs of the digitalization of the economy.

At the moment, the implemented and used ERP and CRM systems (Enterprise Resource Planning and Customer Relationship Management systems) can be considered indicators of the development of the digitalization process. The cut for 2019 on the use of these systems in world practice reflects Figure 3.

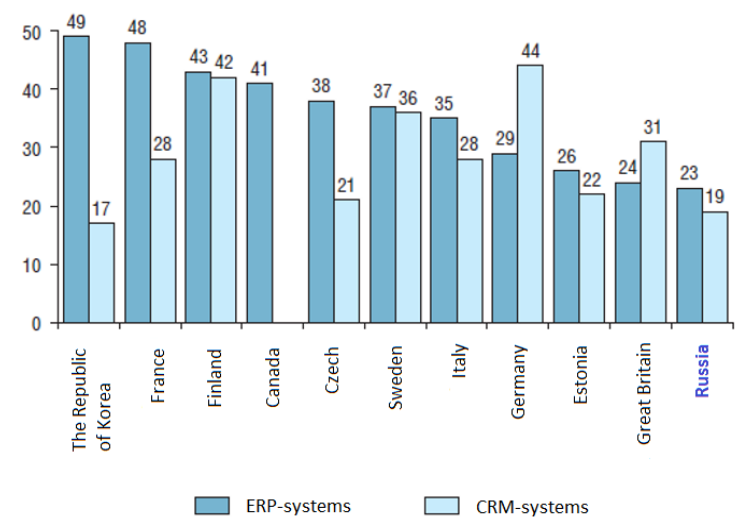

Figure 3. Use of ERP and CRM systems in organizations by country in 2019 (or coming years for which data are available), as a percentage of the total number of enterprises in the business sector Source: [19] 
Despite the ERP boom of the early 2000s, when the introduction of ERP systems at large enterprises became a vital necessity for Russian business leaders, the share of organizations using these systems is in the region of $20 \%$, significantly lagging behind many other countries.

Equally important for Russian entrepreneurship is the introduction of SCM systems (Supply Chain Management systems), affecting all aspects of business development, including the complex of logistics systems management and EAM (Enterprise Asset Management).

The use of ERP-, CRM- and SCM-systems in Russian organizations by type of economic activity shows that the leading position is occupied by organizations in the sphere of wholesale and retail trade and telecommunications (Table 1).

ERP systems responsible for enterprise resource planning and one of the most common categories of business software include MRP and MRP II (Material Requirement Planning) systems. Currently, there are a large number of automated MRP and MRP II systems on the market, which have both a number of advantages and certain disadvantages.

For the right choice of a particular system, it is necessary to proceed from the specifics of production and the capabilities of the company, since different programs cost differently and are aimed at different areas of production.

Table 1. Use of ERP-, CRM-, SCM-systems in Russian organizations in 2019 (as a percentage of the total number of business sector organizations)

\begin{tabular}{|c|c|c|c|}
\hline Type of Economic Activity & ERP-systems & CRM-systems & SCM-systems \\
\hline Entrepreneurial sector & 23.3 & 18.6 & 10.6 \\
\hline Mining operation & 22.7 & 11.9 & 7.7 \\
\hline Manufacturing industry & 29.6 & 18.5 & 6.9 \\
\hline Energy supply & 20.9 & 10.6 & 4.8 \\
\hline Water supply, sanitation, organization of collection and disposal of waste & 6.7 & 23.3 & 18.6 \\
\hline Building & 10.9 & 22.7 & 11.9 \\
\hline Wholesale and retail trade & 37.5 & 33.2 & 23.7 \\
\hline Transport and storage & 20.2 & 12.4 & 6.8 \\
\hline Activities of hotels and catering establishments & 20.9 & 13.3 & 8.8 \\
\hline Telecommunications & 46.1 & 43.1 & 13.0 \\
\hline Information technology industry & 23.7 & 22.3 & 6.2 \\
\hline Operations with real estate & 7.5 & 6.7 & 2.4 \\
\hline Professional, scientific and technical activities & 12.1 & 9.5 & 3.7 \\
\hline
\end{tabular}

Source: [19]

There are a large number of successful examples of the implementation of ERP and MRP systems in production [20-22]. So, for example, the introduction of MRP systems in the Federal State Unitary Enterprise "GKNPTs named after M.V. Khrunichev", the leading enterprise of the rocket and space industry in Russia [20].

The answer to the challenges of digitalization of the economy is offered by the fourth industrial revolution, or Industry 4.0 (I4.0). The results of the study presented in the work of M. Gotz and B. Jankowska [16] illustrate the use of CRM and ERP systems in the analyzed companies. Companies that ignore (or try to ignore) the formation of digital networks and the optimization of value chains, risk, as the authors note, to quickly lose their competitive position.

The use of digital technologies in the electric power industry contributes to a more rational consumption of resources by both producers and consumers, a reliable and even distribution of energy resources. The analysis of big data on consumer behavior enables suppliers to form flexible tariffs depending on energy consumption patterns $[17,18]$.

Today, three key areas can be distinguished in the management of fixed assets of an enterprise: EAM (Enterprise Asset Management) - asset management, MRO (Maintenance, Repair and Overhaul) - maintenance and repair management, and APM (Advanced Power Management) - asset performance management, including end-to-end monitoring of IT infrastructure. Each of these areas has its own characteristics, but more often they are all considered as elements of the EAM. For example, APM systems help to keep fixed assets in working condition, ensuring their continuous "diagnostics" and timely repairs, as well as to more reasonably prioritize equipment replacement.

EAM are automated control systems, the objects of which can be production assets of any complexity (including buildings, structures, working machines, equipment, communications and infrastructure) with reference to location and specifications. They are based on qualitative descriptions of all elements of 
assets, standards, work plans (PPR) and flow charts, processes for registering incidents, issuing work orders, etc. All this is included in the standard functionality of the "classic" EAM system.

This is a tool not so much for the top management of companies as for chief engineers, specialists in the field of production processes. Just as at one time Russian financial directors had to go through a difficult path of realizing the need to implement ERP systems, so do domestic enterprises' producers have to overcome the path of realizing the need not only to modernize physical assets, but also to effectively manage them, in which their maintenance and repair are optimally organized, which impossible without advanced digital technologies.

In the conditions of high physical and moral depreciation of fixed assets, which is typical for most Russian enterprises, it is necessary to automate the management of maintenance and repair processes (EAM), which, unfortunately, is not yet perceived by Russian technical managers as a primary task.

According to L. Vinokurov [14], "if we consolidate data from various IT publications and from EAM solution providers, it turns out that about a thousand EAM projects have been implemented in Russia. Consequently, $90 \%$ of the 10 thousand largest Russian enterprises and organizations do not have modern automated EAM management systems."

Businesses will be able to recoup the costs of acquiring and installing EAM systems by reducing the cost of repair and maintenance of fixed assets, reducing their downtime and reducing the number of breakdowns. The next step in the development of digitalization and the use of digital tools may be the introduction of technologies such as the Internet of things, predictive analytics, artificial intelligence, BIM, access from mobile devices, cloud environments, etc. Unfortunately, it will not be effective to use them without the introduction of basic EAM models, and sometimes it's just not possible.

The formation of reserves for increasing the efficiency of fixed assets lies in their most rational use, the application of new developments based on digital solutions. At the same time, one should not forget about the need to train personnel capable of using these tools, and about creating the most comfortable working conditions, because these factors are also important components of enterprise performance.

\section{DISCUSSION}

In itself, the use of digital tools will not ensure the efficient use of fixed assets without qualified personnel trained in a timely manner at the enterprise. Critical assets are growing in number and variety and are becoming increasingly difficult to manage, maintain and repair. Fixed assets are becoming more intelligent, and the requirements for specialists and personnel are ever higher, based on the knowledge of new technologies. There are risks here that are not fully understood at the moment. It is no coincidence that A. Sorgner in his work notes "that additional research is required to develop educational strategies aimed at protecting workers from the consequences of digitalization of production" [15].

The introduction of EAM is not so much a matter of digitalization as of the actual management of the maintenance and repair of fixed assets.

Many of those who are responsible for the serviceability and performance of equipment, production and transport facilities (primarily chief engineers) have yet to realize that fixed assets need to be managed efficiently, optimizing their use, maintenance and repair. And in order to perform this task efficiently and at the lowest cost, you need to use advanced digital tools and technologies. This is not just a tribute to fashion or a trend of the times, it is a necessity for the successful functioning of a business in a competitive environment.

\section{CONCLUSION}

Russia, like many countries, is actively introducing digital tools in all spheres of life. They play an especially important role in business development. The leaders of the domestic business sector of the economy in the use of digital tools are organizations of such types of economic activity as telecommunications, wholesale and retail trade, manufacturing industry, information technology industry. Unfortunately, organizations of most types of economic activities do not have a sufficiently high digitalization index.

With regard to the digitalization of fixed assets management, a similar situation is observed. In Russia, there is a rather large gap between leading enterprises (about 10\%) that are at the frontier of digital transformation, and a large number of companies (the remaining 90\%) that have not even reached the basic level of implementation of digital tools in fixed asset management. This also applies to 
the automation of maintenance and repair processes. Undoubtedly, there are successful practices in the use of digital tools that ensure the effective management of fixed assets, proving the correctness of this direction of modernization of domestic enterprises.

For most organizations, the task of digital transformation of fixed asset management is the phased introduction of digital innovation tools. In other words, it is advisable to implement a basic EAM management model, on the basis of which other digital tools (Internet of Things, predictive analytics, BIM, etc.) can then be implemented.

\section{AUTHORS' CONTRIBUTIONS}

Tatyana V. Kudryashova - statement of the research problem; scientific leadership; formulation of the main concept of the study; critical analysis; formulation of conclusions; development of recommendations and revision of the text. Elena F. Zhukova - selection of materials; critical analysis; preparation of the text of the article. Natalya V. Subbotina - literature review on the problem under study, preparation of graphic results of the study; development of recommendations.

\section{REFERENCES}

[1] A.V. Kleyman, "Topical issues of the management of fixed capital in the enterprises of the Russian Federation", Fundamental Research, 2014, vol. 5(2), pp. 308-313. (In Russ.).

[2] V.A. Lesniak, "The economic substance of the fixed assets and their identification in accounting”, Terra Economicus, 2013, vol. 11(1-2), pp. 54-59. (In Russ.).

[3] G.V. Kolesnik, M.B. Rybakov, "A model to optimize the structure of enterprise's fixed assets in conditions of digital transformation", Economic Analysis: Theory and Practice, 2021, vol. 20(2-509), pp. 357-378. (In Russ.). DOI: 10.24891/ea.20.2.357

[4] V.K. Gorbunov, V.P. Krylov, "Region effective production assets and their assessment by the production function method", Economy of Region, 2015, vol. 3(43), pp. 334-347. (In Russ.). DOI: 10.17059/2015-3-27

[5] N.V. Arsenieva, L.M. Putyatina, N.V. Tarasova, "Methodological Aspects of a Comprehensive Analysis of the Fixed Capital of Machine Building Enterprises”, Economies, 2020, vol. 8, p. 73. DOI: 10.3390/economies 8030073

[6] L.V. Davydova, S.A. Ilminskaya, "Fixed capital management policy as part of the overall financial strategy of an enterprise", Finance and Credit, 2019, vol. 15, pp. 5-11. (In Russ.).

[7] V.V. Oganezov, "Improvement of capital management" [Sovershenstvovanie upravleniya kapitalom], Innovation Science, 2015, vol 1(41), pp. 91-93. (In Russ.).

[8] A. Parshin, O. Okorokova, "Financial instruments for managing the fixed capital of an enterprise and the specifics of their application in the Russian Federation", The Scientific Heritage, 2021, vol. 66-3(66), pp. 12-15. (In Russ.). DOI: 10.24412/9215-0365-2021-66-312-15

[9] O.V. Demchuk, S.S. Aleksandrov, "Development of an effective enterprise asset management strategy", Financial Economy, 2019, vol. 7, pp. 384-385. (In Russ.).

[10] V. Nakama, "The financial instrumentalization of space: Real estate investment funds as fixed capital structures", Revista INVI, 2021, vol. 36(102), pp. 194-214. DOI: $10.4067 /$ S0718-83582021000300194

[11] F.C. Zhu, W.C. Hu, C.H. Zhang, "Revisiting China's net capital stock and fixed capital consumption for ten types of assets: an improved methodology for 1978-2016", Transformations in Business \& Economics, 2020, vol. 19(3), pp. 542-561.

[12] I.S. Pinkovetskaia, Y.V. Nuretdinova, T.V. Treskova, N.M. Neif, "Estimation of fixed capital investment in Russian SM microenterprises in 2018”, Amazonia Investiga, 2019, vol. 8(21), pp. 42-51.

[13]"90\% of Russian enterprises need transformation and digitalization of maintenance and repairs" [V transformacii i cifrovizacii tekhobsluzhivaniya i remontov nuzhdayutsya $90 \%$ rossijskih predpriyatij], 2020. (In Russ.). Retrieved from https://computerworld.ru/articles/Tsifrovizatsiya -upravleniya-TOiR-kak-vyzov-dlya-rossiyskihglavnyh-inzhenerov

[14]"How modern trends in automation and digitalization affect the management of fixed assets and physical assets of enterprises" [Kak 
sovremennye tendencii avtomatizacii i cifrovizacii vliyayut na upravlenie osnovnymi fondami i fizicheskimi aktivami predpriyatij], 2021. (In Russ.). Retrieved from https://www.computerworld.ru/articles/Upravle nie-osnovnymi-fondami-kurs--na-tsifrovizatsiyu

[15] A. Sorgner, "The Automation of Jobs: A Threat for Employment or a Source of New Entrepreneurial Opportunities?", Foresight and STI Governance, 2017, vol. 11(3), pp. 37-48. DOI: $10.17323 / 2500-2597.2017 .3 .37 .48$

[16] M. Gotz, B. Jankowska, "Adoption of Industry 4.0 Technologies and Company Competitiveness: Case Studies from a PostTransition Economy", Foresight and STI Governance, 2020, vol. 14(4), pp. 61-78. DOI: 10.17323/2500-2597.2020.4.61.78

[17] "Electricity: uncovering value through digital transformation", 2015. World Economic Forum. Retrieved from https://reports.weforum.org/digitaltransformation/electricity-an-industry-ready-fordigitization/

[18] J. Turovets, L. Proskuryakova, A. Starodubtseva, V. Bianco, "Green Digitalization in the Electric Power Industry", Foresight and STI Governance, 2021, vol. 15(3), pp. 35-51. DOI: 10.17323/2500-

\subsection{1}

[19] G.I. Abdrakhmanova, K.O. Vishnevsky, L.M. Gokhberg et al., "Digital economy: 2021: a brief statistical compendium" [Tsifrovaya ekonomika: 2021: kratkij statisticheskij sbornik], M.: NRU HSE, 2021, 124 p. (In Russ.).

[20] A. Vikulina, "Experience of ERP implementation at the enterprise: examples of successful implementation cases", 2019, WISEADVICE-IT. (In Russ.). Retrieved from https://wiseadvice-it.ru/o-

kompanii/blog/articles/opyt-vnedreniya-erp-napredpriyatii-primery-uspeshnyh-keisovvnedreniya-1s-erp/

[21] M.K. Izmaylov, "Comparative Analysis of Modern EAM-Systems Used in Russian and Foreign Practice", BENEFICIUM, 2020, vol. 2(35), pp. 35-42. (In Russ.). DOI: 10.34680/BENEFICIUM.2020.2(35).35-42

[22] M.I. Vlasova, "Analysis of the effectiveness of the implementation of ERP systems in organizations of the construction industry" [Analiz effektivnosti vnedreniya ERP-sistem v organizaciyah stroitel'noj otrasli], Young Scientist [Molodoj Uchenyj], 2018, vol. 49(235), pp. 341-343. (In Russ.). 